\title{
Resistance in U.S. Wheat to Recent Eastern African Isolates of Puccinia graminis f. sp. tritici with Virulence to Resistance Gene Sr31
}

\author{
Y. Jin, USDA-ARS Cereal Disease Laboratory, University of Minnesota, St. Paul; and R. P. Singh, CIMMYT, Apdo, \\ Postal 6-641, Mexico D.F., Mexico
}

\begin{abstract}
Jin, Y., and Singh, R. P. 2006. Resistance in U.S. wheat to recent eastern African isolates of Puccinia graminis f. sp. tritici with virulence to resistance gene Sr31. Plant Dis. 90:476-480.

The stem rust resistance gene $\mathrm{Sr} 31$ derived from rye has been used as an important source of stem rust resistance in many wheat cultivars worldwide. Isolates of Puccinia graminis f. sp. tritici with virulence to Sr31 were identified from Uganda in 1999. Stem rust susceptibility in wheat lines with Sr31 was observed in Kenya in 2003 and 2004. An isolate collected from Uganda in 1999 and an isolate collected from Kenya in 2004, identified to be race TTKS, were used in the rust evaluations. Selected cultivars and advanced breeding lines (450 in total) of wheat from the United States were tested against these two stem rust isolates. Resistance to race TTKS was detected in major classes of wheat with the following frequencies: $16 \%$ of hard red spring wheat, $48 \%$ of hard red winter wheat, and $27 \%$ of soft winter wheat. The genes that conferred resistance in the spring wheat have not been conclusively identified. Resistance in cultivar Ivan was likely due to $S r 24$. Resistance in hard red winter wheat was postulated to be primarily due to $S r 24$, and resistance in soft winter wheat was postulated to be primarily due to $S r 36$. The 1AL.1RS translocation present in many U.S. winter wheat cultivars and breeding lines appears to carry an effective resistance gene different from $\mathrm{Sr} 31$. The presence of resistance to race TTKS in the adapted germ plasm presents an opportunity to improve stem rust resistance in wheat.
\end{abstract}

Stem rust of common wheat (Triticum aestivum) and durum (T. turgidum subsp. durum), caused by Puccinia graminis f. sp. tritici (Pgt), historically was one of the most destructive wheat diseases. Significant losses occurred in the past when the disease developed into epidemic proportions in wheat crops (10). The use of effective resistance in major wheat production regions in North America, in combination with the eradication of the alternate host common barberry (Berberis vulgaris) in the Midwest and northern Great Plains, has brought the disease under control. The use of host resistance was also widespread worldwide. The stem rust resistance gene Sr31, derived from Petkus rye $(6,21)$, has been used worldwide in spring, facultative, and winter wheat through the widespread use of Russian and other East European

Corresponding author: Y. Jin

E-mail: yuejin@umn.edu

Mention of trademark, vendor, or proprietary product does not constitute a guarantee or warranty of the product by the USDA and does not imply its approval to the exclusion of other products or vendors that also may be suitable.

Accepted for publication 8 November 2005.

\section{DOI: 10.1094/PD-90-0476}

This article is in the public domain and not copyrightable. It may be freely reprinted with customary crediting of the source. The American Phytopathological Society, 2006. wheat Kavkaz, Aurora, and Loverin that originally carried the 1BL.1RS wheat-rye translocation (20). When used initially, the 1BL.1RS translocation provided resistance to stem rust, leaf rust (caused by $P$. triticina), stripe rust (caused by $P$. striiformis), and powdery mildew (caused by Erysiphe graminis f. sp. tritici). This led to the release of numerous popular cultivars worldwide including several spring wheat cultivars derived from the spring wheat germ plasm in CIMMYT (International Maize and Wheat Research Center, Mexico). Although resistance to leaf rust, stripe rust, and powdery mildew became ineffective in most wheat growing areas shortly after the deployment of the 1BL.1RS translocation, gene $S r 31$ provided the main component for stem rust resistance in many wheat cultivars and continued to remain effective until recently, when isolates of $P$. graminis f. sp. tritici with virulence to $\operatorname{Sr} 31$ were detected from Uganda in 1999 (9). Similar virulence was observed in Kenya in 2003 and 2004 (19). The objectives of this study were to assess the vulnerability of U.S. wheat to African and U.S. isolates and to identify wheat germ plasm that displayed resistance.

\section{MATERIALS AND METHODS}

An isolate (99UGA) of $P$. graminis $\mathrm{f}$. sp. tritici collected from Uganda in 1999 and one (04KEN156) collected from Kenya in 2004, both identified as race TTKS (19) based on the 16 differentials in the Pgt differential set of North America (12), were used for evaluating the wheat lines. Two Pgt isolates of races TPMK and TTTT, representing broad virulence in the North American stem rust population, were included for comparisons of infection types. A total of 450 cultivars and advanced breeding lines from various wheat market classes from the United States were tested with the four Pgt isolates at the seedling stage. Cultivars and lines that exhibited resistance in the initial tests were tested a second time to confirm the resistance.

Urediniospores of $P$. graminis f. sp. tritici isolates from long-term storage in liquid nitrogen or in $\mathrm{a}-80^{\circ} \mathrm{C}$ freezer were heat-shocked at $40^{\circ} \mathrm{C}$ for $10 \mathrm{~min}$ and placed in a rehydration chamber for 2 to 4 $\mathrm{h}$ where approximately $80 \%$ relative humidity $(\mathrm{RH})$ was maintained by a $\mathrm{KOH}$ solution (14). The urediniospores were then suspended in a lightweight mineral oil (Soltrol 170) and inoculated onto the fully expanded primary leaves of 7-day-old seedlings of wheat lines. Seedlings were incubated in a dew chamber for $14 \mathrm{~h}$ at $18^{\circ} \mathrm{C}$ in the dark, and then for an additional period of 3 to $4 \mathrm{~h}$ under fluorescent light. The inoculated plants were placed on a greenhouse bench at $18 \pm 2^{\circ} \mathrm{C}$ with a photoperiod of $16 \mathrm{~h}$. Infection types (IT) described by Stakman et al. (16) were assessed 14 days postinoculation. Probable genes conferring resistance to race TTKS in cultivars and breeding lines were postulated where possible by comparison of infection types on wheat lines with known stem rust resistance genes and by inferences based on pedigree information. A set of the 16 Pgt differentials and the susceptible checks McNair 701, Chinese Spring, and LMPG-6 were used in each inoculation. Infection types $0, ;, 1,2$, or combinations thereof were considered low infection types produced by an isolate of the pathogen avirulent on seedlings of wheat carrying the corresponding resistance gene. Infection types 3 to 4 were considered high infection types, indicating susceptibility of the host line due to a lack of the corresponding resistance gene, or a lack of the avirulence gene in the pathogen isolate.

\section{RESULTS AND DISCUSSION}

Resistance in U.S. hard red spring wheat. Among the 84 cultivars and advanced breeding lines of U.S. hard red spring wheat from the northern Great 
Plains region tested in this study, $16 \%$ were resistant or heterogeneous (i.e., having resistant and susceptible plants in the same line) to race TTKS. In contrast, 93\% were resistant to race TTTT and 94\% were resistant to race TPMK. Hard red spring wheat cultivars that exhibited low infection types to race TTKS are given in Table 1 . The cultivar Thatcher was heterogeneous for reaction to race TTKS: plants with two different low infection types, i.e., IT; (flecking) and 2, as well as high infection types 3 and 4, were observed. Because most of these resistant cultivars were related to Thatcher by their pedigrees, resistance to race TTKS in these cultivars is likely due to one or two genes derived from Thatcher. The identities of genes conditioning resistance to race TTKS in Thatcher are unknown. Several $\mathrm{Sr}$ genes, namely $\operatorname{Sr} 5,9 g, 12$, and 16 , are known to be present in Thatcher $(4,5)$. Single gene lines with $\operatorname{Sr} 5$ and $9 g$ were susceptible to race TTKS (19). Lines with $\operatorname{Sr} 12$ and 16 were not tested against race TTKS. Additional genes conditioning stem rust resistance in Thatcher were reported $(3,8)$, but these genes have not been characterized or designated yet. Single gene lines with Sr13, 22, 24, 25, 26, 27, 29, 32, 33, 35, 36, 40 , and 44 had low infection types to TTKS (19). None of these designated $\mathrm{Sr}$ genes are known to be present in these spring wheat cultivars except for $\mathrm{Sr} 24$, which is likely present in the cultivar Ivan. Ivan was determined to carry Lr24 (J. Kolmer, personal communication), and $\mathrm{Sr} 24$ is expected to be present because $\mathrm{Sr} 24$ and $\mathrm{Lr} 24$ are completely associated (6).

Most of the hard red spring wheat cultivars currently grown or released in recent years in the northern Great Plains region were susceptible to race TTKS at the seedling stage (Table 2). A single gene line

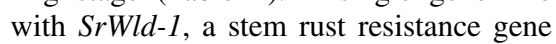
derived from the cultivar Waldron with resistance to many North American races of $P$. graminis f. sp. tritici (7), was susceptible to race TTKS at the seedling stage (data not shown). This degree of stem rust susceptibility to a single race in the hard red spring wheat from the northern Great Plains region has not been observed previously. It may indicate that the virulence combination of race TTKS is very unusual. More likely, however, it may indicate a serious erosion of the resistance package in the spring wheat germ plasm that has provided stable stem rust resistance in the region for over 50 years. Recent emphasis in breeding for Fusarium head blight resistance might have contributed to the dilution of stem rust resistance in spring wheat. Although some advanced breeding lines of hard red spring wheat were found to be resistant to race TTKS at the seedling stage (data not shown), we do not expect more than two genes present in these breeding lines that confer resistance to race
TTKS. Thus, there is an urgent need to improve the level and diversity of stem rust resistance, especially resistance to race TTKS, in the spring wheat germ plasm.

Resistance in U.S. hard red winter wheat. Approximately 200 cultivars and breeding lines of hard red and hard white winter wheat from the Great Plains region were tested. Nearly half of the lines (48\%) were found to be resistant to race TTKS. Selected cultivars that exhibited low infection types to race TTKS are given in Table 3. Probable genes conferring resistance to race TTKS in these cultivars were postulated based on the differential reactions to the test isolates (Table 4). Pedigree information was also used to support the gene postulation. Cultivars with $\mathrm{Sr} 24$ were resistant to race TTKS with infection types ranging from 1 to $2+$. Cultivars with $\mathrm{Sr} 36$

Table 1. Infection types produced by four isolates of Puccinia graminis f. sp. tritici on seedling plants of selected hard red spring wheat cultivars resistant to race TTKS

\begin{tabular}{lccccc}
\hline & & \multicolumn{4}{c}{ Isolate $^{\left(\text {race }^{\mathbf{a}}\right)}$} \\
\cline { 3 - 6 } Cultivar & $\begin{array}{c}\text { Year of } \\
\text { release }\end{array}$ & $\begin{array}{c}\text { 04KEN156 } \\
\text { (TTKS) }\end{array}$ & $\begin{array}{c}\text { 98UGA } \\
\text { (TTKS) }\end{array}$ & $\begin{array}{c}\text { 01MN84A } \\
\text { (TTTT) }\end{array}$ & $\begin{array}{c}\text { 74MN1049 } \\
\text { (TPMK) }\end{array}$ \\
\hline Thatcher & 1935 & $; / 2 / 3^{\mathrm{b}}$ & $; / 2 / 3$ & $; 23$ & $; 12$ \\
Chris & 1965 & $; 2$ & $; 2$ & 0 & 0 \\
Guard & 1983 & $1 / 4$ & $1 / 4$ & 0 & 0 \\
Stoa & 1984 & 2 & 2 & $;$ & 0 \\
Keene & 1996 & 2 & 2 & $; 1$ & $2-$ \\
Ivan & 1998 & 2 & 2 & 2 & $; 1$ \\
Ember & 1999 & $2 / 4$ & $2 / 4$ & 0 & 0 \\
LMPG-6 & & 3 & 3 & 3 & 34 \\
McNair 701 & & 4 & 4 & 34 & 4 \\
Chinese Springc & & 4 & 4 & 34 & 4 \\
\hline
\end{tabular}

${ }^{a}$ Pgt race code, after Roelfs and Martens (12); the fourth set consists of genes $\operatorname{Sr} 9 a, 9 d$, 10, and $\operatorname{Tmp}(11)$.

${ }^{\mathrm{b}}$ Indicating the cultivar was heterogeneous for reaction to the test isolate; the predominant plant type was given first.

${ }^{\mathrm{c}}$ Susceptible check.

Table 2. Infection types produced by four isolates of Puccinia graminis f. sp. tritici on seedling plants of selected currently grown or recently released hard red spring wheat cultivars

\begin{tabular}{lccccc}
\hline & & \multicolumn{4}{c}{ Isolate (race } \\
\cline { 3 - 6 } Cultivar & Year of & 04KEN156 & 98UGA & 01MN84A & 74MN1049 \\
(Telease & (TTKS) & (TTKS) & (TTT) & (TPMK) \\
\hline Alsen & 2000 & $3+$ & 4 & $0 ;$ & 0 \\
Argent & 1998 & 4 & 4 & $12 ;$ & 2 \\
Briggs & 2002 & 3 & 3 & 0 & 0 \\
Dapps & 2003 & 3 & 4 & $; 1$ & $;$ \\
Granger & 2004 & 4 & 4 & 0 & $0 ;$ \\
Granite & 2001 & $3+$ & $3+$ & $; 1$ & 0 \\
Gunner & 1996 & 3 & $3+$ & 2 & 2 \\
Ingot & 1998 & $3+$ & 4 & $;$ & 0 \\
Keystone & 2001 & 4 & 4 & $; 1$ & 0 \\
Knudson & 2001 & 4 & 4 & 4 & $23-$ \\
McVey & 2001 & 4 & 4 & 0 & 0 \\
Norpro & 1999 & 3 & $3+$ & $; 1$ & 0 \\
Oklee & 2003 & 3 & 4 & 0 & 0 \\
Oxen & 1996 & 4 & 4 & 0 & 0 \\
Parshall & 1999 & $3+$ & $3+$ & 2 & $0 ;$ \\
Reeder & 1999 & 4 & 4 & $; 1$ & $; 1$ \\
Steele-ND & 2004 & $3-$ & $3-$ & $;$ & $; 2$ \\
Walworth & 2001 & $3+$ & 3 & $;$ & 2 \\
LMPG-6 & & 3 & 3 & 3 & 34 \\
McNair 701 & & 4 & 4 & 34 & 4 \\
Chinese Spring & & 4 & 4 & 34 & 4 \\
\hline
\end{tabular}

${ }^{a}$ Pgt race code, after Roelfs and Martens (12); and the fourth set consists of genes $\operatorname{Sr} 9 a, 9 d, 10$, and $\operatorname{Tmp}(11)$.

b Susceptible check. SrTmp to race TTKS was mostly 2 to $2-$. Sr36 and SrTmp were ineffective against tion type 3, although lines with Sr36 exhibited a low infection density (reduced to race TTTT. Cultivars that had a low or 0 ; to race TPMK but presence of $\mathrm{Sr} 31$ was postulated based on ef this gene to the the 1BL.1RS translocation identified by

winter wheat was postulated to be mostly hard red winter wheat (Table 3) was likely exhibited a low infection type, mostly 0 , to due to $S r 24$. The high frequency of $S r 24$ in 
Table 3. Infection types produced by four isolates of Puccinia graminis $\mathrm{f}$. sp. tritici on seedling plants of selected hard red and hard white wheat cultivars resistant to race TTKS

\begin{tabular}{|c|c|c|c|c|c|}
\hline \multirow[b]{2}{*}{ Cultivar } & \multicolumn{4}{|c|}{ Isolate $\left(\right.$ race $\left.^{\mathbf{a}}\right)$} & \multirow[b]{2}{*}{$\begin{array}{c}\text { Postulated } \\
\text { Sr gene }\end{array}$} \\
\hline & $\begin{array}{c}\text { 04KEN156 } \\
\text { (TTKS) }\end{array}$ & $\begin{array}{l}\text { 98UGA } \\
\text { (TTKS) }\end{array}$ & $\begin{array}{c}\text { 01MN84A } \\
\text { (TTTT) }\end{array}$ & $\begin{array}{c}\text { 74MN1049 } \\
\text { (TPMK) }\end{array}$ & \\
\hline Alliance & 2 & $2+$ & $3+$ & $3+$ & $T m p$ \\
\hline Amigo $^{c}$ & 0 & 0 & 2 & 2 & $24,1 R S-A m^{\mathrm{d}}$ \\
\hline $\mathrm{AP} 502^{\mathrm{c}}$ & $1+$ & 2 & 2 & 0 & $1 R S-A m, 6$ \\
\hline Arapahoe & $2-$ & $2-$ & $1+$ & 0 & 24,6 \\
\hline Avalanche & $1 / 3^{e}$ & $; / 2 / 3$ & $2 / 4$ & 2 & 24 \\
\hline Cimarron & 1 & 2 & 2 & $2+$ & 24 \\
\hline Cisco & 2 & 2 & $3+$ & 0 & Tmp, 6 \\
\hline Coronado & $2 / 3+$ & $2 / 3$ & $2 / 3$ & 0 & 24,6 \\
\hline Cutter & $; 1$ & 1 & $2-$ & $1+$ & 24 \\
\hline Golden Spike & 2 & 2 & 4 & 4 & $T m p$ \\
\hline Goodstreak & $2+$ & $2+3-$ & 4 & 0 & Tmp, 6 \\
\hline Halt $^{\mathrm{c}}$ & $1+$ & 1 & 3 & $2+$ & $1 R S-A m$ \\
\hline Harry & 1 & $-^{\mathrm{f}}$ & ; & 0 & 24,6 \\
\hline Ike & $2+$ & $2+$ & 4 & $0 / 2-$ & Tmp, 6 \\
\hline Intrada & 1 & ; & 2 & 2 & 24 \\
\hline Jagalene & $2-$ & $2-$ & 1 & ; & 24,6 \\
\hline Larned & $2+$ & $2+$ & 4 & $2 / 4$ & $T m p$ \\
\hline Millennium & 2 & 2 & $3 / 2$ & 4 & $T m p$ \\
\hline Nekota ${ }^{c}$ & $2+$ & $2+$ & $3+/ ; 1$ & 0 & $1 R S-A m, 6$ \\
\hline NuHills & $; 1$ & - & $; 1$ & $; 1$ & $?^{\mathrm{g}}$ \\
\hline Nuplains & $2-$ & $2-$ & 2 & 2 & 24 \\
\hline Ogallalac & 2 & 2 & 2 & 2 & 24 \\
\hline OK102 & 1 & - & $2-$ & 2 & 24 \\
\hline Pecos & $; 12$ & $; 12$ & 2 & $2 / 3$ & $?$ \\
\hline Prairie $\operatorname{Red}^{\mathrm{c}}$ & 2 & $2+$ & 2 & 2 & $1 R S-A m$ \\
\hline Red Chief & $2+$ & $2+$ & 4 & 4 & $?$ \\
\hline Sage & 2 & 2 & 2 & 2 & 24 \\
\hline Siouxland & 1 & 1 & 2 & 2 & 24,31 \\
\hline Stanton & 2 & 2 & 2 & $0 ; / 3$ & 24,6 \\
\hline TAM 105 & $2+$ & $2+$ & 4 & 4 & $T m p$ \\
\hline TAM $107^{\mathrm{c}}$ & $1+$ & $1+$ & 2 & 2 & $1 R S-A m$ \\
\hline TAM $110^{c}$ & $1+$ & $1+$ & $2-$ & 2 & $1 R S-A m$ \\
\hline TAM $200^{c}$ & $; 1$ & ; & 2 & 2 & 24, IRS-Am \\
\hline Trego & $1+$ & $1+$ & 2 & ; & 24 \\
\hline Vista & 0 & 0 & 3 & 2 & 36 \\
\hline Wesley & 2 & $2 / 3$ & $; / 3$ & - & 24 \\
\hline Windstar & $1+$ & 1 & $1+$ & 0 & 24,6 \\
\hline LMPG-6 ${ }^{\mathrm{h}}$ & 3 & 3 & 3 & 34 & \\
\hline McNair $701^{\mathrm{h}}$ & 4 & 4 & 34 & 4 & \\
\hline Chinese Springh & 4 & 4 & 34 & 4 & \\
\hline
\end{tabular}

a Pgt race code, after Roelfs and Martens (12); the fourth set consists of genes $\operatorname{Sr} 9 a$, 9d, 10, and $\operatorname{Tmp}(11)$.

b Postulated $\mathrm{Sr}$ gene for resistance to TTKS and other races.

c Presence of 1AL.1RS translocation identified by Graybosch (1).

${ }^{\mathrm{d}}$ Resistance to race TTKS due to $1 \mathrm{AL} .1 \mathrm{RS}$ derived from Amigo.

e Indicating the cultivar was heterogeneous for reaction to the test isolate; the predominant plant type was given first.

${ }^{\mathrm{f}}$ Missing data.

$\mathrm{g}$ The gene identity for resistance to race TTKS could not be postulated based on available data from this study.

h Susceptible check.

Table 4. The main and range of infection types produced by three races of Puccinia graminis $\mathrm{f}$. sp. tritici on selected wheat lines that contain specific stem rust resistance genes

\begin{tabular}{lcccc}
\hline & & \multicolumn{1}{c}{ Race } & \\
\cline { 2 - 4 } Line & Sr gene & TTKS & TPMK & TTTT \\
\hline ISr6-Ra & Sr6 & $\mathrm{H}^{\mathrm{a}}$ & $0 ;(0 \text { to } ;)^{\mathrm{b}}$ & $\mathrm{H}$ \\
LcSr24Ag & $S r 24$ & $2(1$ to $2+)$ & $2(1$ to $2+)$ & $2(1$ to $2+)$ \\
Kavkaz & $S r 31$ & $\mathrm{H}$ & $; 1(;$ to 2$)$ & $; 1(;$ to 2$)$ \\
W2691SrTt-1 & $S r 36$ & $0(0$ to $;)$ & $\mathrm{H}^{\mathrm{c}}$ & $\mathrm{H}$ \\
CnsSrTmp & $S r T m p$ & $2(2-$ to 2$)$ & $\mathrm{H}$ & $\mathrm{H}$ \\
LMPG-6 $^{\mathrm{d}}$ & & $\mathrm{H}$ & $\mathrm{H}$ & $\mathrm{H}$ \\
McNair 701 $^{\mathrm{d}}$ & & $\mathrm{H}$ & $\mathrm{H}$ & $\mathrm{H}$ \\
Chinese Spring $^{\mathrm{d}}$ & & $\mathrm{H}$ & $\mathrm{H}$ & $\mathrm{H}$ \\
\hline
\end{tabular}

a High infection types (3 to 4), indicative of host susceptibility.

${ }^{b}$ Predominant type (and range) of infection types observed.

c TPMK produces a low density of uredinia on lines with Sr36.

d Susceptible check. a result of it being a source of resistance to both leaf rust and stem rust. Isolates of $P$. graminis f. sp. tritici virulent to $S r 24$ have not been identified in North America; thus this gene will continue to serve as a valuable source of stem rust resistance in the hard winter wheat region. Resistance to race TTKS due to SrTmp was postulated to be present in several hard red winter wheat cultivars (Table 3 ). The resistance gene SrTmp was derived from the cultivar Triumph 64 (13). Races of $P$. graminis f. sp. tritici with virulence to $S r T m p$ in the North American stem rust population have been rare except for those isolates in the race groups 15 and 56 on the Stakman's differentials (16), and race TTTT detected recently (2). Races 56 and 15 caused widespread epidemics in North America in the 1930s and 1950s, respectively. By inference, the presence of SrTmp in hard red winter wheat may have played a significant role in preventing other major races from developing into epidemic proportions in North America by reducing the overwintering population size of $P$. graminis f. sp. tritici in the southern Plains and by reducing inoculum in the growing season. On the other hand, the use of SrTmp in the southern winter wheat region has likely played a large role in selecting for and maintaining race TPMK as the predominant race in the North American stem rust population for several decades.

Several hard red winter wheat cultivars appeared to have the 1AL.1RS translocation (Table 3). This translocation was likely derived from Amigo (15), which carries a translocation from Insave rye (Secale cereale). This translocation was thought to be independent of the 1BL.1RS translocation derived from Petkus rye (19), which carries the rust resistance genes Sr31, $L r 26$, and $\operatorname{Yr}$ 9. A stem rust resistance gene on 1RS in Amigo was reported (17), but the authors could not determine whether this gene was $S r 31$ based on their stem rust isolates. All cultivars with the 1AL.1RS translocation in this study were resistant to race TTKS. The presence of $\mathrm{Sr} 24$ in some of the 1AL.1RS cultivars, i.e., Amigo, Ogallala, and TAM 200, could explain the resistance to race TTKS. Resistance to race TTKS in other 1AL.1RS cultivars, i.e., AP502, Halt, Prairie Red, TAM 107, and TAM 110, is likely due to an undesignated gene on 1RS reported by The et al. (17), because these cultivars do not seem to carry $\mathrm{Sr} 24$ based on their susceptibility to a leaf rust isolate that was avirulent on Lr24 (data not shown) and many other leaf rust isolates (D. Long, personal communication). If the resistance to race TTKS in these cultivars was due to a gene on 1RS, then it is apparent that this resistance gene on 1RS from Amigo could not be Sr31. In addition, Amigo exhibited an infection type 0 to race TTKS, considerably lower than that of either $S r 24$ or the undesignated gene on 1RS. Among the 
designated stem rust resistance genes that exhibited an infection type 0 to race TTKS; thus gene Sr36 might be present in cultivar Vista (Table 3).

Resistance in U.S. soft winter wheat. Resistance to race TTKS in cultivars and breeding lines of soft winter wheat was 28 and $37 \%$, respectively. Selected cultivars with TTKS resistance are given in Table 5. Most of the resistance was likely due to Sr36, a gene common in U.S. soft winter wheat cultivars. The presence of $\mathrm{Sr} 36$ in cultivars and breeding lines was relatively easy to recognize in this study because lines with Sr36 exhibited very low infection types, mostly 0 , to race TTKS, and high infection types ( 3 to 4 ) to races TTTT and TPMK. Gene Sr24 appeared to be present in cultivars Fleming, McCormick, and Morey (Table 5) and several breeding lines (data not shown). Cultivars Fleming and McCormick also have the 1AL.1RS translocation for resistance to race TTKS in addition to $\mathrm{Sr} 24$. Thus, these cultivars could serve as valuable sources of resistance in breeding for resistance to race TTKS. The high level of resistance to races TTKS, TMPK, and TTTT exhibited by Rosen could not be postulated. Few genes are known for exhibiting IT 0 or 0 ; to races TTKS, TPMK, and TTTT. The cultivar may possess unknown resistance genes or useful combinations.

Stem rust has been effectively controlled through the use of resistant cultivars in tested in this study, $\mathrm{Sr} 36$ was the only gene

wheat for more than 50 years in North America. Although the new African stem rust race TTKS appears to have unprecedented virulence, effective resistance genes are available in adapted U.S. wheat cultivars and elite breeding germ plasm. The level of adult plant resistance, traditionally an important part of stem rust resistance, has not been investigated with regard to this African race. A trial to determine the presence of adult plant resistance has been established in Kenya. In addition to $\mathrm{Sr} 24$, Sr36, and SrTmp, we have found high levels of resistance conditioned by unknown genes in cultivars and breeding germ plasm in all major classes of U.S. wheat. Furthermore, a number of designated (but not utilized) stem rust resistance genes, namely $\operatorname{Sr} 13,22,25,26,27,29,32$, $33,35,40$, and 44 , are effective against race TTKS and many other stem rust races. A rapid deployment of these effective resistance genes in breeding programs will provide protection of wheat against this new race or others that may appear. The stem rust resistance gene $\mathrm{Sr} 31$ became widely distributed worldwide through the use of CIMMYT wheat germ plasm (18). Race TTKS will likely pose an immediate threat to wheat production in regions, especially developing countries, where $S r 31$ has been used as the primary component for stem rust resistance in commercial cultivars. Wheat improvement for stem rust resistance in these regions, particularly with respect to race TTKS, should be pro-

Table 5. Infection types produced by four isolates of Puccinia graminis f. sp. tritici on seedling plants of selected soft winter wheat cultivars that are resistant to race TTKS

\begin{tabular}{|c|c|c|c|c|c|}
\hline \multirow[b]{2}{*}{ Cultivar/line } & \multicolumn{4}{|c|}{ Isolate (race $\left.{ }^{\mathbf{a}}\right)$} & \multirow[b]{2}{*}{$\begin{array}{c}\text { Postulated } \\
\text { Sr } \text { gene }^{\mathbf{b}} \\
\end{array}$} \\
\hline & $\begin{array}{c}\text { 04KEN156 } \\
\text { (TTKS) }\end{array}$ & $\begin{array}{l}\text { 98UGA } \\
\text { (TTKS) }\end{array}$ & $\begin{array}{c}\text { 01MN84A } \\
\text { (TTTT) }\end{array}$ & $\begin{array}{l}\text { 74MN1049 } \\
\text { (TPMK) }\end{array}$ & \\
\hline AGS $2000^{c}$ & $2+$ & 2 & $; 1$ & $2 / 4^{\mathrm{d}}$ & $1 R S-A m^{\mathrm{d}}$ \\
\hline Cayuga & 2 & 2 & 4 & 0 & Tmp, 6 \\
\hline CK 9323 & 0 & 0 & 4 & 4 & 36 \\
\hline CK 9474 & $; 1$ & 0 & $-^{\mathrm{e}}$ & 3 & 36 \\
\hline CK 9663 & 0 & 0 & 3 & 0,3 & 36 \\
\hline CK 9766 & $; 1$ & 0 & 4 & 4 & 36 \\
\hline CK 9803 & 0 & 0 & $3+$ & 0 & 36 \\
\hline CK 9835 & $; 1$ & 0 & 4 & 2 & 36 \\
\hline Ernie & 0 & 0 & ;3- & ; & 36,6 \\
\hline Fleming ${ }^{\mathrm{c}}$ & 0 & ;1/3- & $; 12$ & 0 & $36,24,1 R S-A m, 6$ \\
\hline GA-Stuckey & 0 & 0 & 0 & $0 ; / 2$ & $36,6,31$ \\
\hline Jaypee & 0 & 0 & 3 & $3-$ & 36 \\
\hline LA422 & 0 & 0 & 3 & $3+$ & 36 \\
\hline McCormick $^{\mathrm{c}}$ & $1+$ & $1+$ & $2-$ & $2-$ & $24,1 R S-A m$ \\
\hline Morey & 1 & 1 & $; 1$ & $; 1$ & 24,31 \\
\hline NC Neuse & ; & ; & 4 & $; 2$ & 36 \\
\hline Rosen & 0 & 0 & 0 & 0 & 36 \\
\hline Sawyer & 0 & 0 & ; & ; & 36,31 \\
\hline Sisson & 0 & 0 & $; 1-$ & 0 & $36,6,31$ \\
\hline LMPG- $6^{\mathrm{f}}$ & 3 & 3 & 3 & 34 & \\
\hline McNair $701^{f}$ & 4 & 4 & 34 & 4 & \\
\hline Chinese Spring $\mathrm{f}$ & 4 & 4 & 34 & 4 & \\
\hline
\end{tabular}

${ }^{a}$ Pgt race code, after Roelfs and Martens (12); the fourth set consists of genes $\operatorname{Sr} 9 a, 9 d$, 10, and $\operatorname{Tmp}(11)$.

${ }^{\mathrm{b}}$ Postulated $\mathrm{Sr}$ gene for resistance to TTKS and other races.

${ }^{c}$ Presence of 1AL.1RS translocation identified by Graybosch (1).

${ }^{\mathrm{d}}$ Indicating the cultivar was heterogeneous for reaction to the test isolate; the predominant plant type was given first.

${ }^{\mathrm{e}}$ Missing data.

${ }^{\mathrm{f}}$ Susceptible check. moted. The use of effective resistance in northern Africa, western and southern Asia, and the Middle East will slow the spread of this new race because these are the regions the new race will likely spread into first. A thorough survey of race composition and close monitoring of the development of new races worldwide will be necessary to understand fully the potential stem rust vulnerability in wheat.

\section{ACKNOWLEDGMENTS}

We thank A. P. Roelfs and J. A. Kolmer for critical review of the manuscript.

\section{LITERATURE CITED}

1. Graybosch, B. 1RS status of entries, 1993present. U.S. Dep. Agric. Agric. Res. Serv. Published online: http://arslincoln.unl.edu/ wheat/default.htm.

2. Jin, Y. 2005. Races of Puccinia graminis identified in the United States during 2003. Plant Dis. 89:1125-1127.

3. Knott, D. R. 2000. The inheritance of stem rust resistance in Thatcher wheat. Can. J. Plant Sci. 80:53-63.

4. Kolmer, J. A., Dyck, P. L., and Roelfs, A. P. 1991. An appraisal of stem and leaf rust resistance in North American hard red spring wheats and the probability of multiple mutations to virulence in populations of cereal rust fungi. Phytopathology 81:237-239.

5. Luig, N. H. 1983. A survey of virulence genes in wheat stem rust, Puccinia graminis f. sp. tritici, Advances in plant breeding, Supplement II to Journal of Plant Breeding. Berlin, Germany.

6. McIntosh, R. A., Wellings, C. R., and Park, R. F. 1995. Wheat Rusts: An Atlas of Resistance Genes. CSIRO, Australia.

7. McVey, D. V., and Roelfs, A. P. 1978. Stem rust resistance of the cultivar 'Waldron'. Pages 1061-1065 in: Proc. Int. Wheat Genet. Sympos. 5th. S. Ramanujam, ed.

8. Nazareno, N. R. X., and Roelfs, A. P. 1981 Adult plant resistance of Thatcher wheat to stem rust. Phytopathology 71:181-185.

9. Pretorius, Z. A., Singh, R. P., Wagoire, W. W., and Payne, T. S. 2000. Detection of virulence to wheat stem rust resistance gene $\mathrm{Sr} 31$ in Puccinia graminis f. sp. tritici in Uganda. Plant Dis. 84:203.

10. Roelfs, A. P. 1978. Estimated losses caused by rust in small grain cereals in the United States 1918-76. U.S. Dep. Agric. Agric. Res. Serv., Misc. Publ. 1363.

11. Roelfs, A. P., Long, D. L., and Roberts, J. J. 1993. Races of Puccinia graminis in the United States during 1990. Plant Dis. 77:125-128.

12. Roelfs, A. P., and Martens, J. W. 1988. An international system of nomenclature for $\mathrm{Puc}$ cinia graminis f. sp. tritici. Phytopathology 78:526-533.

13. Roelfs, A. P., and McVey, D. V. 1975. Races of Puccinia graminis in the United States during 1974. Plant Dis. Rep. 59:681-685.

14. Rowell, J. B. 1984. Controlled infection by Puccinia graminis f. sp. tritici under artificial conditions. Pages 292-332 in: The Cereal Rusts, Vol. 1. Origins, Specificity, Structure, and Physiology. W. R. Bushnell and A. P. Roelfs, eds. Academic Press, Orlando, FL.

15. Sebesta, E. E., Wood, E. A., Jr., Porter, D. R., Webster, J. A., and Smith, E. L. 1995. Registration of Amigo wheat germplasm resistant to greenbug. Crop Sci. 35:293.

16. Stakman, E. C., Steward, D. M., and Loegering, W. Q. 1962. Identification of physiologic races of Puccinia graminis var. tritici. U.S. Dep. Agric. Agric. Res. Serv. E-617.

17. The, T. T., Gupta, R. B., Dyck, P. L., Appels, R., Hohmann, U., and McIntosh, R. A. 1992. 
Characterization of stem rust resistant derivatives of wheat cultivar Amigo. Euphytica 58:245-252.

18. Villareal, R. L., and Rajaram, S. 1988. Semi dwarf bread wheats, names, parentages, pedigrees, and origins. CIMMYT, Mexico, D.F

19. Wanyera, R., Kinyua, M. G., Jin, Y., and Singh,
R. P. 2006. The spread of stem rust caused by Puccinia graminis f. sp. tritici, with virulence on Sr31 in wheat in Eastern Africa. Plant Dis. 90:113.

20. Zeller, F. J. 1973. 1B/1R wheat-rye chromosome substitutions and translocations. Pages 209-221 in: Proc Int. Wheat Genet. Sympos. 4th. E. R. Sears and L. M. S. Sears, eds. University of Missouri, Columbia.

21. Zeller, F. J., and Hsam, S. L. K. 1983. Broadening the genetic variability of cultivated wheat by utilizing rye chromotin. Pages 161 173 in: Proc. Intl. Wheat Genet. Sympos. 6th S. Sakamoto, ed. Kyoto, Japan. 